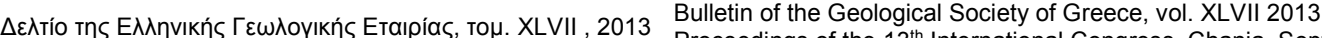
Proceedings of the $13^{\text {th }}$ International Congress, Chania, Sept.

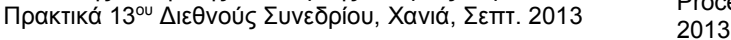

\title{
GEOLOGICAL SOLUTIONS CONCLUDED BY PETROLEUM GEOCHEMICAL DATA IN WESTERN GREECE
}

\author{
Rigakis N. ${ }^{1}$, Karakitsios V. ${ }^{2}$, Marnelis F. ${ }^{1}$ and Sotiropoulos Sp. ${ }^{1}$ \\ ${ }^{1}$ Hellenic Petroleum S.A. Exploration and Production of Hydrocarbons, $8^{A}$, Chimaras Str., 15125, \\ Maroussi,Athens,nrigakis@helpe.gr,fmarnelis@helpe.gr,ssotiropoulos@helpe.gr \\ ${ }^{2}$ National and Kapodistrian University of Athens, Faculty of Geology and Geoenvironment, \\ Department of Hist. Geology - Paleontology, vkarak@geol.uoa.gr
}

\begin{abstract}
A detailed petroleum geochemical study has been performed in the previous years in the Western Greece. Several source rock horizons have been identified, the oil window has been calculated for the most significant sub-basins and the oil correlation study has distinguished the different oil groups of the area, generated from different hydrocarbon sources. These results are very significant and useful for the oil exploration. But, further to these, some more geochemical observations can also be very important on solving some geological problems of the area.

- A major problem is the deposition and preservation of the organic matter in the Western Greece.

- The dolomitization in relation with the oil generation is also an issue.

- Another issue is the calculation of the eroded overburden formations thickness.

- The Paleogeothermal gradient determination is also very important.

The last two parameters are absolutely necessary for organic matter maturity calculations.

The study of all the above parameters completes the geochemical study of the Western Greece, and in relation with other geological studies can provide solutions in the petroleum exploration of the area.

Key words: organic matter, paleogeothermal gradient, dolomitization, hydrocarbon exploration.
\end{abstract}

\section{Пврі́⿱一}

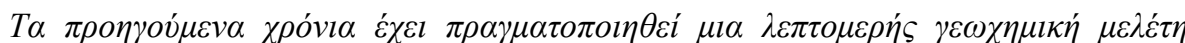

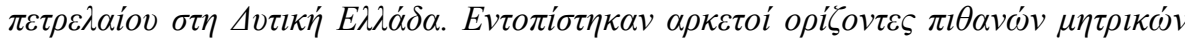

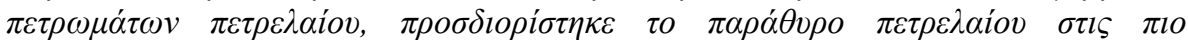

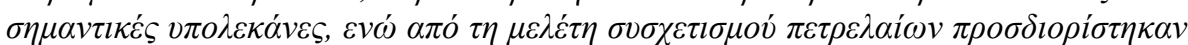

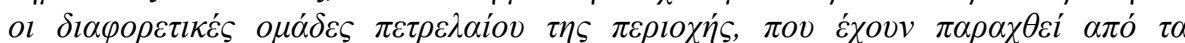

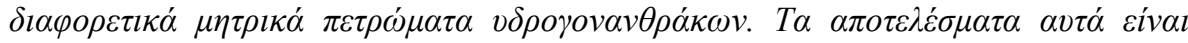

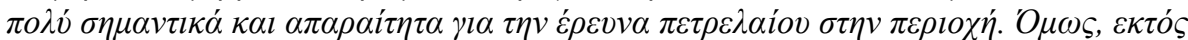

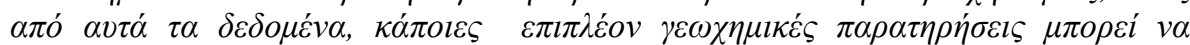




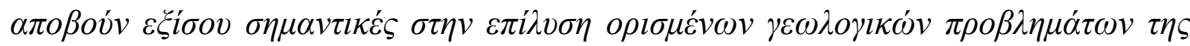
$\Delta v \tau \imath \kappa \eta ́ \varsigma ~ E \lambda \lambda \alpha \dot{\delta} \delta \alpha$.

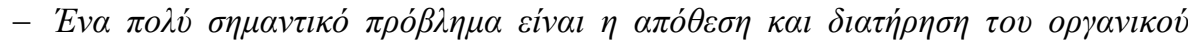

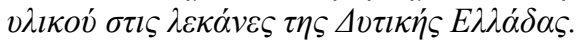

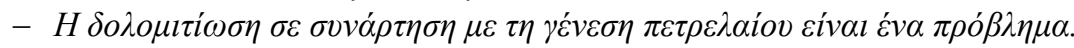

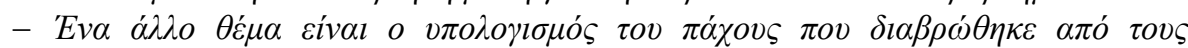

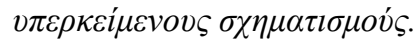

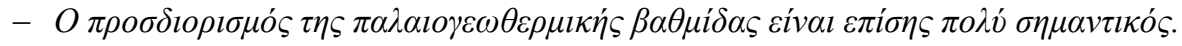

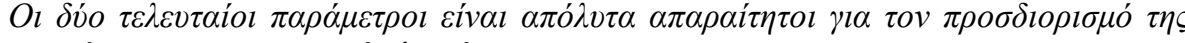

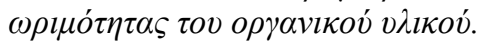

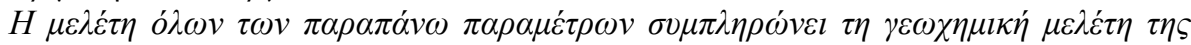

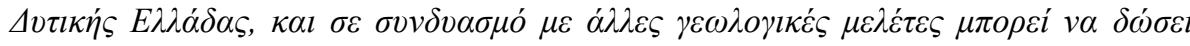

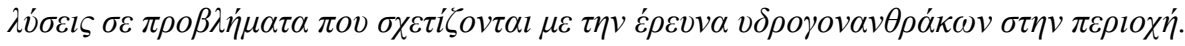

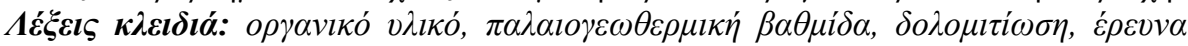

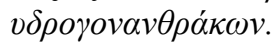

\section{Introduction}

Geological provinces of Greece are subdivided in to geotectonic zones, based on their paleogeographic position and the evolution of their formations. The Gavrovo, Ionian and Paxi (or Pre-Apulian) are the most External (western) zones of Greece (Figure 1). They are mainly consisted from sedimentary rocks, and for this reason their petroleum generation potential had been studied in details; their organic matter quantity, quality and maturity had been studied, as well as the timing of oil generation and the origin of the surface oil seeps and drilled oil shows (Rigakis, 1999; Rigakis \& Karakitsios, 1998; Karakitsios \& Rigakis, 2007; Rigakis et al., 2007). The results are helpful for the identification of the petroleum potential of Western Greece.

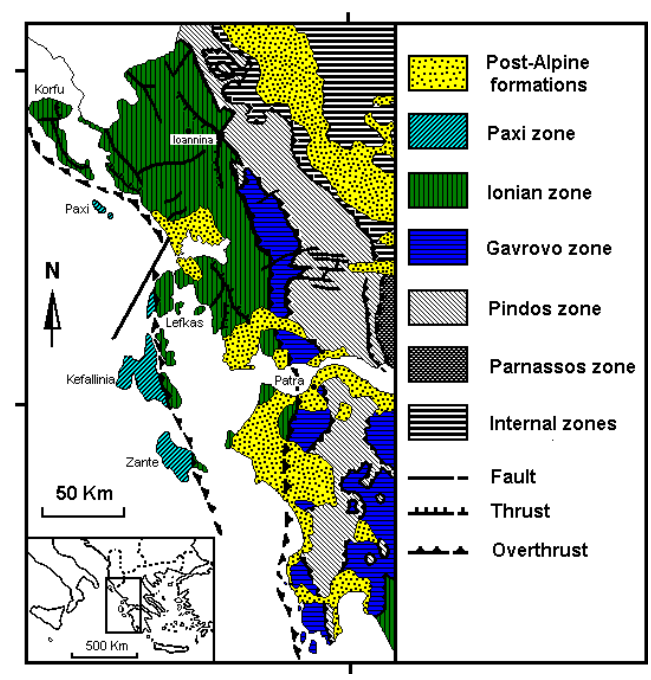

Figure 1 - Geotectonic map of Western Greece.

The Gavrovo zone consists of platform carbonates, deposited in a high-energy intertidal environment. The outcropping sequence comprises Lower Cretaceous to Eocene limestones followed by the Oligocene flysch (BP, 1971). The Ionian zone is a basin which was formed during the Middle Lias between Apulian and Gavrovo platforms. It can be divided into the Internal (eastern), Central and External (western) Ionian (IGRS-IFP, 1966). The Ionian zone is made up of three distinct stratigraphic sequences (Karakitsios, 1995): The pre-rift sequence is represented by

XLVII, No 3 - 2132 
Triassic evaporites, and overlain Foustapidima and Pantokrator limestones (Middle Triassic-Early Liassic). The syn-rift sequence is characterized by unconformities and great thickness and facies variations. The complete sequence includes the Siniais and Louros limestones (Pliensbachian), the Ammonitico Rosso or Lower Posidonia Beds (Toarcian-Aalenian), the "Limestones with Filaments" (Bathonian-Callovian) and the Upper Posidonia Beds (Oxfordian-Tithonian). The postrift sequence comprises the Vigla limestones (Lower Cretaceous), the Senonian and the PaleoceneEocene limestones followed by Oligocene flysch. Clastic sediments of Aquitanian and Burdigalian overly unconformably the flysch, in the central and western areas of the Ionian zone (IGRS-IFP, 1966). In Paxi zone the older formations are Upper Triassic dolomites, followed by Lower Jurassic evaporites and limestones, Middle-Upper Jurassic limestones, anhydrites and shales, Lower Cretaceous carbonates, Upper Cretaceous limestones, Paleocene-Eocene limestones, Oligocene limestones and Miocene-Pliocene marly limestones and marls (Bornovas, 1964; Dermitzakis, 1978; Rigakis, 1999). In Figure 2, the simplified stratigraphic columns of the External zones are presented, and the stratigraphic position of the hydrocarbon source rocks is indicated.

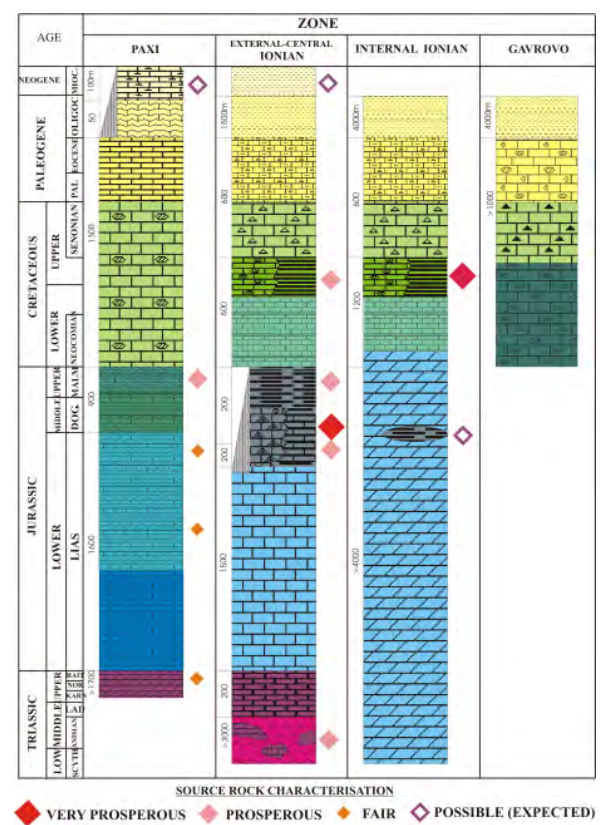

Figure 2 - Stratigraphy and hydrocarbon source rocks in Western Greece.

\section{Hydrocarbon Source Rocks Presence and Maturity}

The main hydrocarbon source rocks in the Western Greece are the Vigla shales, the Posidonia Beds and the Triassic shale fragments in Ionian zone and the Upper Jurassic shales in Paxi zone (Rigakis, 1999; Rigakis \& Karakitsios, 1998; Karakitsios \& Rigakis, 2007).

Especially in the Internal Ionian zone the main source is the Vigla shales, member of Vigla formation, dated in the interval Albian-Cenomanian, which are rich to very rich in organic matter. The most promising horizons are found in two intervals. Zone A': 3120-3270m, with total organic carbon (TOC) up to $11.7 \%$ and petroleum potential (PP) up to $60.9 \mathrm{mg} / \mathrm{g}$. Zone B': $3375-3580 \mathrm{~m}$, with TOC up to $4.8 \%$ and PP up to $23.5 \mathrm{mg} / \mathrm{g}$. The very high hydrogen indexes in relation to the very low oxygen indexes and also their maceral content indicate a type I to II organic matter, capable for oil generation. The differences in the results between the two intervals and the increased maturity show that, these horizons are indeed two different ones (Rigakis, 1999). 
The Vigla source rocks are mature in the location of Agios Georgios-3 well, drilled in Arta syncline, since the onset of oil generation is identified at $2950 \mathrm{~m}$ depth, as concluded from vitrinite reflectance (Ro\%) measurements and confirmed by Rock Eval data (Tmax and PI), and biomarker maturity ratios. The oil window in the deeper parts of the sub-basin is calculated by maturity models to be in the interval 3450-5600m depth (Rigakis, 1999).

In the Central and External Ionian the most prosperous hydrocarbon source rock is the Lower Posidonia Beds (Rigakis, 1999, Rigakis \& Karakitsios, 1998), which contain high quantities of organic matter in many outcrops and in all the wells where they were drilled. The higher values are measured in the thin-bedded marls of Dragopsa-1 well; TOC up to $19.1 \%$, PP up to $125.8 \mathrm{mg} / \mathrm{g}$. Their organic matter type is I to II capable for generation of high quantities of oil.

Secondary but quite significant source rocks are the Vigla shales, which are rich in organic matter in outcrops and drilled wells. Another quite prosperous source rock is the Upper Posidonia Beds which also contain high petroleum potential. Finally the shale fragments incorporated in the Triassic breccias and gypsum, which are the surface expression of Triassic evaporites (Karakitsios \& Pomoni-Papaioannou, 1998), are very rich in TOC (up to 16.1\%) and in PP (up to $98.8 \mathrm{mg} / \mathrm{g}$ ), with a type I organic matter, capable for oil generation in the interval 1250-1270m of Ioannina-1 well (Karakitsios \& Rigakis, 1996).

Several parameters have been examined for estimating the thermal maturity of the potential source rocks. The maturity of the outcrop samples is generally low since these horizons have been emerged prior to the maturation of their organic matter. More reliable measurements have resulted from wells' samples. According to that the oil window in the deeper parts of Botsara syncline is estimated to be in the interval $3750-5800 \mathrm{~m}$. Based on this observation, Posidonia Beds are mature in terms of oil generation. The degree of organic matter maturation is generally low, but it favors the generation and preservation of oil in deep areas from possible source rocks under the Triassic evaporites. In areas where extensive Triassic formations are outcropping, the oil window is found in shallow depths, between 1000-3600m (Rigakis, 1999; Rigakis \& Karakitsios, 1998).

In the Paxi (Pre-Apulian zone) the most prosperous source rock is the Aptici shales of the MiddleUpper Jurassic carbonates, as concluded from Paxi-Gaios-1X well. There have been identified horizons very rich in organic matter, with a TOC up to $5.5 \%$, PP up to $41.5 \mathrm{mg} / \mathrm{g}$ and a type II organic matter capable for oil generation. Secondary source rocks have been identified inside the Lower Jurassic and Triassic formations, but their organic matter has been decreased due to their high maturity (Rigakis, 1999; Karakitsios \& Rigakis, 2007).

Their organic matter maturity had been calculated by Vitrinite reflectance (Ro\%) measurements; the oil window is found in the interval $1850-3260 \mathrm{~m}$ depth. This depth is also confirmed by biomarker maturity ratios. In the deeper parts of Paxi basin the oil window is estimated to be in the interval 5600-7250m (Rigakis, 1999; Karakitsios \& Rigakis, 2007).

\section{Geological Observations Based on Geochemical Data}

\subsection{Deposition and Preservation of High Organic Matter Amount}

The deposition and preservation of high organic matter quantities in Vigla shales is characteristic for this formation in the Internal Ionian zone. According to the published data and based on our observations, this procedure can be attributed:

1. To the anoxic events of Cenomanian/Turonian OAE2, early Albian Paquier OAE1b and Aptian-Albian Selli OAE1a (Farrimond et al., 1990; Kuhnt et al., 1990; Bralower et al., 1994; Herrle, 2002) that were recorded in the Cretaceous black shales of the Vigla limestones formation (Karakitsios et al., 2010; Karakitsios et al., 2007; Tsikos et al., 2004; Danelian et al., 2004 respectively). The alternations of oxic-anoxic sedimentary conditions 
resulted in the deposition and preservation of organic matter in thin-bedded horizons. These are cyclic phenomena which are related to the climatic conditions (Ebukanson \& Kinghorn, 1985; Huang et al., 1996). The duration of the cycle is low for the upper stratigraphic layers, while for the deeper horizons the duration is quite long.

2. To the high organic matter supply, due to the significant deposition rates, as concluded by the great formation thickness. So the organic matter passed quickly, without any alteration, through the oxygenated layers and was preserved in low oxygen areas, formed by the oxygen deficiency due to high oxygen demand (Habib, 1982; Farrimond et al., 1990). We believe that this process favored the high organic matter preservation into the two rich Vigla intervals (A' and $\left.\mathrm{B}^{\prime}\right)$, the main petroleum source rocks of the whole area. Another possibility is that anoxia in the photic zone was the main factor for organic matter preservation during the Vigla shales deposition.

In the Central and External Ionian zone remarkable organic matter quantities have been deposited during Lower Cretaceous in Vigla shales horizons, during Jurassic in horizons of Upper and Lower Posidonia Beds and finally during Triassic in shaly horizons (Karakitsios \& Rigakis, 1996; Rigakis \& Karakitsios, 1998; Rigakis, 1999). The conditions of deposition and preservation of the above horizons are more or less the same for Cretaceous and Jurassic formations, but they are different for the Triassic formations (Rigakis \& Karakitsios, 1998).

The organic matter accumulation in the syn-rift formations of Early Toarcian through Tithonian is a result of upwelling (Jenkyns, 1985). Organic matter preservation is directly related to the geometry of the syn-rift period of the Ionian basin. The geometry of the restricted sub-basins favored water stagnation and consequently the development of locally anoxic conditions in the bottom waters (Karakitsios, 1995). Anoxic conditions occurred locally even during the post-rift period in the areas where the Vigla shales (Albian-Cenomanian), lithological member of Vigla formation, is well developed; these areas probably represent sub-basins that were preserved due to the continuation of halokinetic movements during the post-rift period. The well-documented early Toarcian OAE, Aptian-Albian Selli OAE1a, early Albian Paquier OAE1b and Cenomanian/Turonian OAE2 oceanic anoxic events that affected the entire Tethys Ocean, reinforced the anoxia for smaller time intervals as these are recorded in the thin but most organically rich black shale horizons of the corresponding stratigraphic levels. These horizons although cannot by themselves be considered as source rocks (because of their small thickness) they contribute to the oil potential of the whole source rocks (Karakitsios et al., 2007; Karakitsios et al., 2010). So, the local sub-basins geometry during the syn-rift and post-rift period of Ionian zone together with OAEs favored the preservation of the significant organic matter quantities, which are identified in the Lower Posidonia Beds of Toarcian age and in the Vigla shales of Albian-Cenomanian age (Rigakis \& Karakitsios, 1998; Rigakis, 1999).

The dimension of the source rock horizons corresponding to the Lower Posidonia Beds is a significant problem, because it directly affects the quantities of generated hydrocarbons. Questions are raised first because this formation presents great thickness variations and second because in many outcrops the formation is eroded and altered with low organic matter. Two acceptances can be set:

1. The lower organic matter content is because of secondary alteration of these horizons due to external factors, which in some cases left intact the most resistant horizons. Alteration mainly affected the sediments in the surface till some meters in depth, where can act the climatic conditions; for this reason this formation whenever has been drilled contains horizons rich in organic matter (Rigakis \& Karakitsios, 1998; Rigakis, 1999).

2. The organic matter decrease is due to the low quantities of organic matter deposition. According to the tectonic model of the syn-rift period that led to the deposition of prismatic syn-sedimentary wedges (Karakitsios, 1995), high amounts of organic matter were deposited and preserved in the deeper areas (depocenters) of the half grabens, while this

$\underline{\text { XLVII, No } 3 \text { - } 2135}$ 
amount was reduced towards the shallower areas. This aspect is strengthened by the fact that in some outcrops, like the Paliogrimbiani section (Rigakis, 1999), only the deepest shale horizon contains significant amounts of organic matter, while the overlying horizons present low TOC content. Obviously this deeper horizon was deposited in an anoxic environment that changed to more oxic (with the progressive filling of the graben) in the upper horizons of the formation. After the exposition of these horizons to the surface conditions, their organic matter was further reduced due to secondary alterations. Evidently the Ioannina-1 and Dragopsa-1 wells were drilled in areas corresponding to the deepest parts of the half-grabens; that account for the high thickness of the sedimentary strata and for the source rock richness found in these wells.

The second interpretation which is directly associated with the depositional model of the area, is considered as more possible, but in some areas the first acceptance works too, which means that the complementary action of both cases can not excluded. According to the second model, the expected hydrocarbon quantities, in the total Ionian basin, are reduced. But, in areas where the Posidonia Beds were deposited in deep and extensive sub-basins, like the Botsara syncline, N. Kerkyra etc., their extensive depocenter accepted very large quantities of organic matter which were preserved, due to the anoxic conditions imposed by the geometry of the sub-basins. So, in these areas, high quantities of hydrocarbons are expected to be generated.

The Triassic breccias of the Ionian zone correspond to typical evaporite dissolution collapse breccias (Karakitsios \& Pomoni-Papaioannou, 1998). It is suggested that, the shale fragments, with significant content in organic matter, incorporated into the Triassic breccias were initially deposited as stratigraphic layers in relatively shallow restricted sub-basins inside the evaporitic basin. The lack of detailed stratigraphy of the evaporitic sequence in Ionian zone does not allow any possible correlation of the shale layers' deposition with any geological event of Triassic age. However, it is known that organic rich sediments are usually deposited in the base of the evaporitic basins (Busson, 1988). In any case it can be accepted that, initially the organic matter preservation was due to eustatic sea level changes (Christiansen et al., 1993; Herbin et al., 1995). After that, the establishment of the evaporitic sedimentation in the entire basin favored the preservation of the organic matter (Powell, 1986, Busson, 1988, Miller, 1990). Consequently, the formation process of the evaporite dissolution collapse breccias also caused the fragmentation of the initially organic rich shale layers, which now appear as organic rich shale fragments incorporated into the Triassic breccias (Karakitsios \& Rigakis, 1996; Rigakis \& Karakitsios, 1998). This process took place in an anoxic environment, so the organic matter did not altered, but it preserved in significant quantities. Obviously, according to the stratigraphic position of this source rock, most of the oil generated by these horizons is expected to be found under the Triassic evaporites, charging laterally possible structures beneath this excellent cap rock.

In Paxi zone finally, the organic matter deposition and preservation are due to upwelling (Farrimond et al., 1990; Rigakis, 1999).

\subsection{Calculation of the Eroded Formation Thickness}

The eroded flysch thickness was calculated by the vitrinite reflectance (Ro) and sonic methods, by using the indigenous flysch horizons (Figure 3).

According to the vitrinite reflectance method (Dow, 1977), the eroded formation thickness can be calculated by the extrapolation of the Ro vs. depth curve till the depth corresponding to the value $\mathrm{Ro}=0.25 \%$. This value corresponds to the maturity degree of the recent-immature sediments. In our case, in order to proceed to the extrapolation of the curve, we have first of all to choose the proper vitrinite measurements. In most cases the analytical results indicate the presence of two vitrinite populations. In the case of carbonates, the population with the low value was coming from caved material, while the population with the higher value was coming from the indigenous formation and was considered as the representative value of this formation. In the case of the

$\underline{\text { XLVII, No } 3-2136}$ 
overlying flysch strata, the opposite thing happens. The population with the high vitrinite reflectance values is coming from reworked-oxidized material, while the population with the lower value was coming from the indigenous formation and was considered as the representative value of flysch (Rigakis, 1999). Based only on the representative values, the maturity vs. depth curve was drawn in a semi logarithmic plot (Figure 3). By this curve is concluded that the upper limit of petroleum generation is located at $2950 \mathrm{~m}$ depth. Analogous depth for the onset of petroleum generation is concluded by other maturity methods (pyrolysis methods and biomarker maturity ratios). The accordance of all these methods supports the accuracy of each one of the used methods and furthermore reinforces the above selection of the proper vitrinite populations.

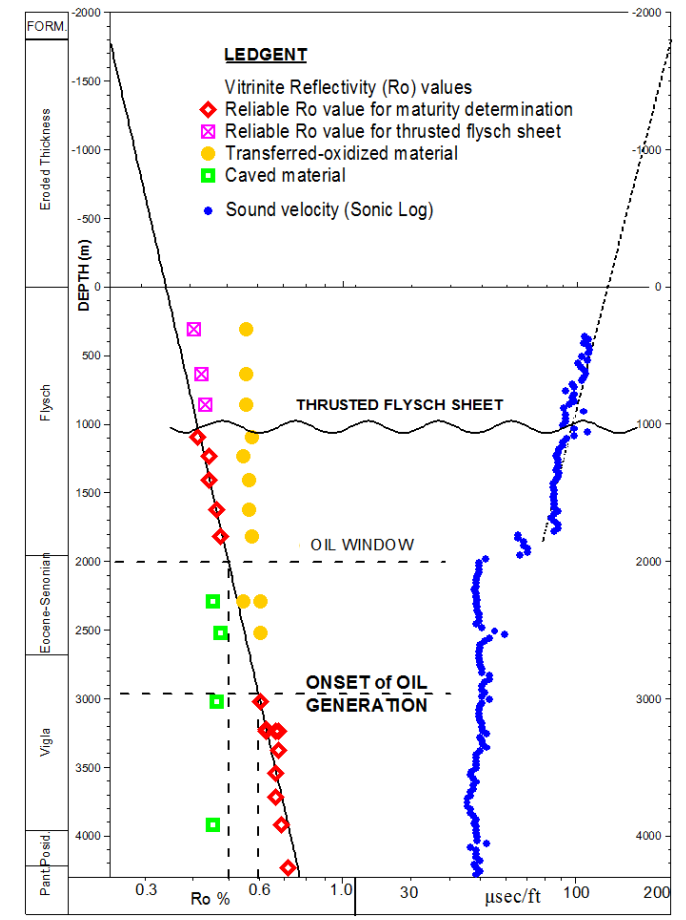

Figure 3 - Vitrinite reflectance (Ro\%) vs. depth and Sonic vs. depth diagram for calculation of the eroded formation thickness.

After choosing the proper vitrinite values and drawing the correct maturity-depth curve, the next step was the extrapolation of this curve till the depth which corresponds to the value $\mathrm{Ro}=0.25 \%$, the maturity degree of the recent-immature sediments. The depth found was $-1780 \mathrm{~m}$. As a result, the eroded formation thickness must be $1780 \mathrm{~m}$. Furthermore, by studying the maturity-depth curve, the presence of a thrust block of flysch was observed at $1050 \mathrm{~m}$ depth (Figure 3 ). The ascertainment was based on the fact that newer sediments of $856 \mathrm{~m}$ depth appear higher maturity degree $(\mathrm{Ro}=0.44 \%)$ than older sediments at $1092 \mathrm{~m}$ depth $(\mathrm{Ro}=0.42 \%)$. Based on the maturity that should hold these sediments, we proceeded to the calculation of the thrust out sediments thickness; this thickness reaches the $500 \mathrm{~m}$. Obviously, in the maturity calculations, the values of the in situ flysch sediments were used and not those of the thrust block (Figure 3).

The sonic method (Magara, 1978) is similar to the vitrinite one for calculation of the eroded formation thickness. It is considered as a fact that in the recent-unconsolidated sediments the sound velocity is almost $1520 \mathrm{~m} / \mathrm{sec}$ (like the water), which corresponds to $200 \mu \mathrm{sec} / \mathrm{ft}$ in the sonic $\log$ measurements. The sonic log values of Agios Georgios-3 well, were plotted in the semi logarithmic plot of the Figure 3 (the "opposite" diagram of the vitrinite one). For the plotting was selected one point every $25 \mathrm{~m}$, which was the average value of the $25 \mathrm{~m}$ interval; measurements 
were taken only from the shale intervals. Looking at this plot, the grate difference between the carbonate units at the bottom of the section and the upper flysch horizons is found at the beginning, as well as a transitional layer of about $170 \mathrm{~m}$ thick. Studying the flysch interval, the presence of the thrust flysch sheet at $1050 \mathrm{~m}$ was confirmed. Like in the vitrinite diagram, the lower lied sediments appear to be less consolidated than the upper ones. So, in order to calculate the formation thickness removed by the erosion, only the in situ-lower flysch sediments were used. A sonic vs. depth curve was created, and afterward this curve was extrapolated till the value of 200 $\mu \mathrm{sec} / \mathrm{ft}$. The depth which corresponds to this value is $-1780 \mathrm{~m}$. That means that the eroded formation thickness is $\mathbf{1 7 8 0} \mathrm{m}$, which is exactly the same with the depth calculated by the vitrinite method.

The accordance of the results of these two methods supports the accuracy of both of them and of the resulted data. This calculated thickness of $1780 \mathrm{~m}$ is the one that was used for the maturity calculations, through maturity models. Furthermore the presence of the flysch thrust sheet, which was observed at $1050 \mathrm{~m}$ depth, helped to a better understanding and a more accurate interpretation of the seismic lines in the surrounding area.

\subsection{Dolomitization}

Another problem of great importance in the Internal Ionian zone is the extensive dolomitization, which has reduced the oil generation capability of some source rocks. It is known (Beales \& Hardy, 1980) that dolomitization can oxidize the organic matter which had deposited and preserved to the sediments. This phenomenon is strong in the case of Agios Georgios-3 well, where the reduction of the organic matter quantity by depth is directly related with the increase of the percentage of the Magnesium Carbonate $\left(\mathrm{MgCO}_{3}\right)$ in the well samples. From Figure 4 which indicates a combination between the percentage of the Total Organic Carbon (TOC) and the percentage of the $\mathrm{MgCO}_{3}$ by depth, it is concluded that:

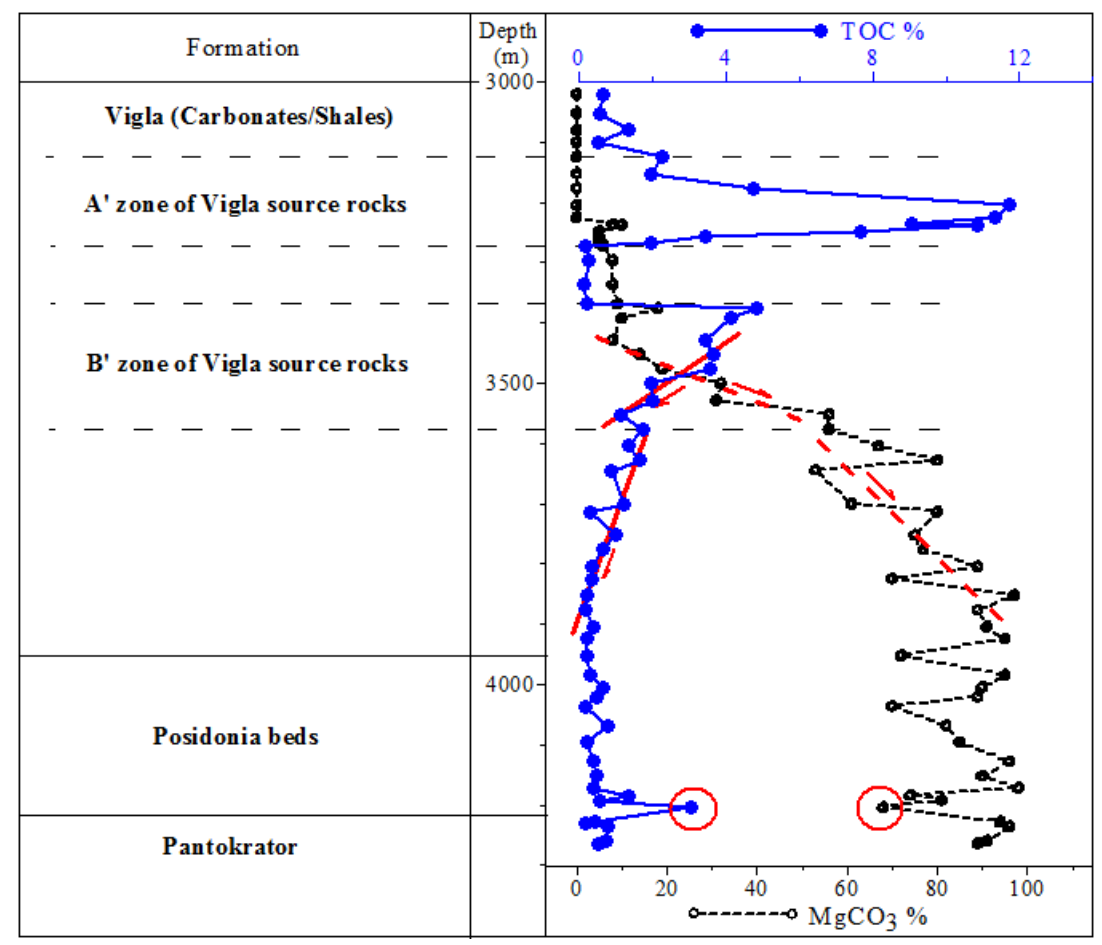

Figure 4 - Dolomitization effects to the organic matter in the formations drilled by Agios Georgios-3 well, Arta syncline.

$\underline{\text { XLVII, No } 3-2138}$ 
1. In the $\mathrm{A}^{\prime}$ zone of Vigla source rocks where the percentage of $\mathrm{MgCO}_{3}$ is almost zero, the source rocks are much more rich in TOC than the source rocks of zone B', where the $\mathrm{MgCO}_{3}$ ranges between 8 and $56 \%$.

2. In the interval between 3476 and $3576 \mathrm{~m}$ of zone B', where the percentage of $\mathrm{MgCO}_{3}$ appears significant increase from 19 to $56 \%$, it is observed a corresponding significant decrease in the TOC content from 4.84 to $1.13 \%$.

3. In the deeper horizons where the $\mathrm{MgCO}_{3}$ increase shows a lower rate (from 67 to $94 \%$ ), the rate of the TOC content decrease is also lower.

4. Posidonia Beds appear low TOC content, obviously due to the dolomitization. But, whenever some Posidonia horizons appear high TOC content, the corresponding $\mathrm{MgCO}_{3}$ percentage is low.

All the above observations indicate that dolomitization has strongly affected the presence of organic matter in the source rock horizons. Further to the results concluded by the diagram, it is also observed in the deeper shale horizons some samples with high TOC content without analogous high petroleum potential values (Rigakis, 1999). This fact is also assigned to the oxidation of the organic matter during dolomitization. This oxidation didn't affect the residual carbon and for this reason the TOC appears high values, while the oxidation reduced the pyrolyzable carbon and the petroleum potential, which are reduced. Furthermore the dolomitization didn't affect the free hydrocarbons (S1). The S1 values remain high, while on the other hand the kerogen values (S2) appear significant reduction. As a result the values of the production index $(\mathrm{PI}=\mathrm{S} 1 / \mathrm{S} 1+\mathrm{S} 2)$ are high; obviously these high $\mathrm{PI}$ values are not only a result of maturation and/or migration, but they have also been affected from the different influence of dolomitization to the S1 and S2 peaks (Rigakis, 1999).

The presence and the extension of dolomitization is a problem for the whole surrounding area. Dolomitization probably extend to a great area since the organic matter of the sediments favors the dolomitization processes, by the contribution of Magnesium ions (Beales \& Hardy, 1980; Zenger \& Dunham, 1980). Furthermore dolomitization is stronger in the deeper layers, where the source rocks expected to be more mature, and as a result to generate higher quantities of hydrocarbons. So, if a big part of their organic matter content has been destroyed, the anticipated hydrocarbon quantities significantly reduced. Of course, these can happen only if dolomitization has affected the source rocks prior to the oil generation process.

The timing of dolomitization is a very critical point, which must be studied very carefully. If dolomitization has started prior to the oil generation, then the anticipated quantities of generated hydrocarbons will be reduced. On the other hand, if the oil generation had already started prior to the dolomitization, then the source rocks would already have generated some quantities of hydrocarbons. About the timing of dolomitization two acceptances can be set:

1. Dolomitization starts during orogenesis and continues after it, because of fracturing and solution circulation, like meteoric waters or hydrothermal liquids (Nichols \& Silberling, 1980). That is the favor case, since the dolomitization takes place after oil generation in most areas, and as a result its influence in the oil-generated quantities is generally low, especially in the basin center, where the oil generation process had started long before orogenesis.

2. Dolomitization has started earlier, after deposition and before or during diagenesis (Dunham \& Olson, 1980). In this case the kerogen was strongly affected and the expected quantities of oil have been reduced, limited mainly to the oil potential of the source rocks located at the sub-basin margins.

All the above mentioned referred especially to the lower-deeper source horizons. Especially the Posidonia Beds, which are strongly dolomitized even in the periphery of the basin, are not anticipated to be potential source rocks. These horizons may have contributed to the oil potential

$\underline{\text { XLVII, No } 3-2139}$ 
of the basin only in the case that dolomitization has taken place after orogenesis that means after the oil generation. Taking into consideration that the oil generation from the Posidonia Beds started during Lower Oligocene and continued till Burdigalian (Rigakis, 1999), these source rocks would had generated their whole petroleum potential before the oxidation of their organic matter. Of course part of this oil may have been lost during orogenesis processes. In any other case it is not anticipated oil from this formation. On the other hand, high quantities of oil in the Internal Ionian zone are expected from the Vigla shales, which were not so much affected by dolomitization, and consequently can be considered as the main source rocks of this sub-basin.

\subsection{Paleogeothermal Gradient Estimation}

A very important application of the maturity calculation through maturity models is the paleotemperature determination; it is achieved by combining the time-temperature index (TTI) calculated by maturity models (Waples, 1980), with the vitrinite reflectivity (Ro) data, which is a very reliable paleo-thermometer (Dow, 1977; Tissot \& Welte, 1984; Katz et al., 1988).

The initial maturity models for the Paxi-Gaios-1X well, indicated that the calculated maturity curve (TTI vs. depth) does not agree at all with the real maturity curve of the sediments, as it is expressed by the Ro vs. depth curve. These modeling attempts used only the present day low geothermal gradients and accepted that the same temperatures had also affected the older formations. The negative correlation of the maturity curves however clearly show that such an assumption does not suffice to describe the paleotemperatures; the difference should be assigned to the increased values of the paleogeothermal gradients, which could be associated with the periods of earth crust thinning (McKenzie, 1981).

After this ascertainment some arbitrary higher paleogeothermal gradients was used, which brought a closure to the curves' "opening". But, the best abridgement of the two curves was achieved after the application of the paleogeothermal gradient values suggested by Professor Pieri (personal communication). The suggestion is that during Triassic times the gradient was $2.5^{\circ} \mathrm{C} / 100 \mathrm{~m}$ and started increasing reached its higher value of $3.5^{\circ} \mathrm{C} / 100 \mathrm{~m}$ during Upper Cretaceous, before the Tethys closure. This high value decrease to $2.5^{\circ} \mathrm{C} / 100 \mathrm{~m}$ during Oligocene times with the flysch deposition and by further decrease reached the today low values (Flores et al., 1991).

By using these paleogeothermal gradients, a very well coincidence of TTI versus depth curve with Ro versus depth curve is obtained (Figure 5). After that, the suggested paleotemperature data are accepted as correct, and were applied for maturity determinations through maturity models in the whole area. These high paleotemperature values mainly affected the older formations, exposed for $\log$ period under high temperatures. On the other hand, the newer formations have been less affected by these paleogeothermal gradients.

\section{Conclusions}

The paleogeographic conditions during deposition and preservation of the organic matter in the Western Greece are not always the same. In the Triassic shales, the preservation of the organic matter was probably a result of eustatic sea level changes, in combination with the evaporite sedimentation. The source rocks of the Jurassic syn-rift formations were deposited in restricted subbasins, whose geometry favored water stagnation, development of local anoxic conditions in the bottom water and organic matter preservation. In the eastern areas of the Ionian basin accumulation and preservation of very high quantities of organic matter in Vigla shales was a result of the high deposition rates. In both the Jurassic and Cretaceous Ionian zone formations, the prevalence of anoxic conditions, during the corresponding oceanic anoxic events, reinforced organic matter preservation. In the Paxi zone deposition and preservation of the organic matter was a result of upwelling movement of seawater.

$\underline{\text { XLVII, No } 3-2140}$ 


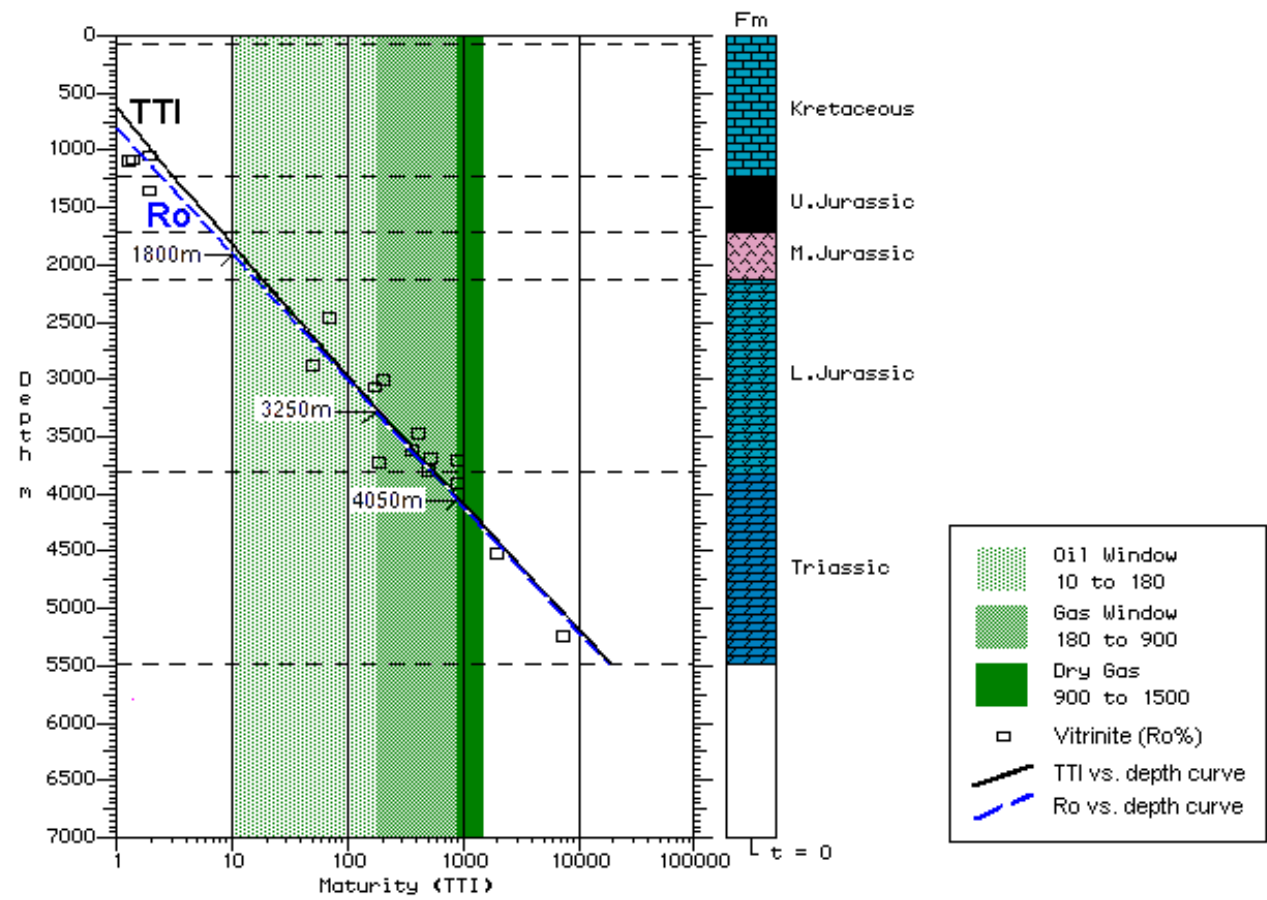

Figure 5 - Paleogeothermal gradient estimation by comparing TTI vs. depth with Ro vs. depth curves in Paxi-Gaios-1X well.

The eroded formation thickness in Internal Ionian zone, calculated by both vitrinite reflectance (Ro) and sonic methods is $1780 \mathrm{~m}$. This thickness was used for maturity calculations through maturity models.

One factor, that affects negatively the oil generation, is the dolomitization in the Internal Ionian zone. In this area, oil can be generated either from the upper horizons-Vigla shales, which are not affected by dolomitization, or from the older horizons-Posidonia Beds, which could have generated oil prior to dolomitization.

The paleogeothermal gradient in the Western Greece was estimated by using vitrinite reflectance (Ro\%) data from the deep well Paxi-Gaios- $1 \mathrm{X}$ in combination with maturity models. This gradient starts from $2.5^{\circ} \mathrm{C} / 100 \mathrm{~m}$ in Triassic, increase to $3.5^{\circ} \mathrm{C} / 100 \mathrm{~m}$ in Upper Cretaceous and decrease to $2.5^{\circ} \mathrm{C} / 100 \mathrm{~m}$ in Oligocene. These data are absolutely necessary for maturity estimations through maturity models.

\section{References}

Beales F. W. and Hardy J. W. 1980. Criteria for the recognition of diverse dolomite types with an emphasis on studies of host rocks for Mississippi valley-type ore deposits, In Zenger D. H., Dunham J. B. and Ethington R. L. (eds.), Concepts and models of dolomitisation, SEPM Special Publication No 28, 197-213.

BP - British Petroleum Corporation Limited 1971. The geological results of petroleum exploration in Western Greece, Institute of Geology and Subsurfuce Research, 10, 73 pp.

Bornovas I. 1964. Geology of Lefkada Island, Institute of Geology and Subsurfuce Research, X/1, $142 \mathrm{pp}$.

Busson G. 1988. Relations entre les types de depots evaporitiques et la presence de couches riches en matiere organique (roches-meres potentielles), Revue de l' Institut Francais du Petrole, 43/2, 181-215.

$\underline{\text { XLVII, No } 3-2141}$ 
Christiansen F. G., Piasecki S., Stemmerik L. and Telnaes N. 1993. Depositional environment and organic geochemistry of the Upper Permian Ravnefield formation source rock in East Greenland, AAPG Bulletin, 77, 1519-1537.

Danelian T., Tsikos H., Gardin S., Baudin F., Bellier J. P. and Emmanuel L. 2004. Global and regional palaeoceanographic changes as recorded in the mid-Cretaceous (Aptian-Albian) sequence of the Ionian Zone (northwestern Greece), Journal of the Geological Society of London, 161/4, 703-709.

Dermitzakis M. 1978. Stratigraphy and sedimentology history of the Miocene of Zakynthos (Ionian Islands, Greece), Annales Geologiues des Pays Helleniques, series 1, XXIX/1, 47186.

Dow W. G. 1977. Kerogen studies and geological interpretations, Journal of Geochemical Exploration, 7, 79-99.

Dunham J. B. and Olsom E. R. 1980. Shallow subsurface dolomitization of subtidally deposited carbonate sediments in the Hanson Greek formation (Ordovician-Silurian) of Central Nevada, In Zenger D. H., Dunham J. B. and Ethington R. L. (eds.), Concepts and models of dolomitisation, SEPM Special Publication, No 28, 139-161.

Ebukanson E. J. and Kinghorn R. R. F. 1985. Kerogen facies in the major Jurassic Mudrock formations of Southern England and the implication on the depositional environments of their precursors, Journal of Petroleum Geology, 8/4, 435-462.

Farrimond P., Eglinton G., Brassell S. C. and Jenkyns H. C. 1989. Toarcian anoxic event in Europe: An organic geochemical study, Marine and Petroleum Geology, 6, 136-147.

Farrimond P., Eglinton G., Brassell S. C. and Jenkyns H. C. 1990. The Cenomanian/Turonian anoxic event in Europe: An organic geochemical study, Marine and Petroleum Geology, 7, $75-89$.

Flores G., Pieri M. and Sestini G. 1991. Geodynamic history and petroleum habitats of the SouthEast Adriatic region. In: Spencer A. M. (ed.), Generation, accumulation, and production of Europe's hydrocarbons, EAPG Special Publication 1, 389-398, Oxford University Press.

Habib A. 1982. Sedimentary supply origin of Cretaceous black shales. In Schlanger S. O. and Cita M. B. (eds.), Nature and Origin of Cretaceous Carbon-rich Facies, Academic Press, 113127.

Herbin J. P., Fernandez-Martinez J. L., Geyssant J. R., Albani A. El., Deconinck J. F., Proust J. N., Colbeaux J. P. and Vidier J. P. 1995. Sequence stratigraphy of source rocks applied to the study of the Kimmeridgian/Tithonian in the North-west European shelf (Dosret/UK, Yorkshire/UK and Boulonnais/France), Marine and Petroleum Geology, 12, 177-194.

Herrle J. O. 2002. Paleoceanographic and paleoclimatic implications on Mid-Cretaceous black shale formation in the Vocontian Basin and the Atlantic: evidence from calcareous nannofossils and stable isotopes, Tuebinger Mikropalaeontologische Mitteilungen, 27, 114 pp.

Huang Z., Williamson M. A., Bateman J., McAlpine K. D. and Fowler M. G. 1996. Cyclicity in the Egret member (Kimmeridgian) oil source rock, Jeanne d' Arc basin, offshore Eastern Canada, Marine and Petroleum Geology, 13/1, 91-105.

IGRS-IFP - Institut de Geologie et Recherches du Sous-sol-Institut Francais du Petrole 1966. Etude geologique de l' Epire (Grece Nord-occidentale), Editions Technip, 306 pp.

Jenkyns H. C. 1985. The Early Toarcian and Cenomanian-Turonian anoxic events in Europe: Comparisons and contrasts, Geologische Rundschau, 74/3, 505-518.

Jenkyns H. C. 1988. The Early Toarcian (Jurassic) anoxic event: Stratigraphic, Sedimentary, and geochemical evidence, American Journal of Science, 288, 101-151.

Karakitsios V. 1995. The influence of preexisting structure and halokinesis on organic matter preservation and thrust system evolution in the Ionian basin, Northwestern Greece, $A A P G$ Bulletin, 79, 960-980.

Karakitsios V. and Rigakis N. 1996. New oil source rocks cut in Greek Ionian basin, Oil \& Gas Journal, 94/7, 56-59. 
Karakitsios V. and Pomoni-Papaioannou F. 1998. Sedimentological study of the Triassic solutioncollapse breccias of the Ionian zone (NW Greece), Carbonates \& Evaporites, 13/2, 207 218.

Karakitsios V. and Rigakis N. 2007. Evolution and petroleum potential of Western Greece, Journal of Petroleum Geology, 30/3, 197-218.

Karakitsios V., Tsikos H., Van Breugel Y., Koletti L., Sinninghe Damste J. S. and Jenkyns H. C. 2007. First evidence for the Cenomanian - Turonian Oceanic Anoxic Event (OAE2 or "Bonarelli" Event) from the Ionian Zone, Western Continental Greece, International Journal of Earth Sciences, 96, 343-352.

Karakitsios V., Kafousia N. and Tsikos H. 2010. Oceanic Anoxic Events as recorded in the Mesozoic sedimentary record of mainland Greece, Hellenic Journal of Geosciences, 45, 123-131.

Katz B. J., Pheifer R. N. and Schunk D. J. 1988. Interpretation of discontinuous vitrinite reflectance profiles, AAPG Bulletin, 72, 926-931.

Kuhnt W., Herbin J. P., Thurow J. and Wiedmann J. 1990. Distribution of Cenomanian-Turonian organic facies in the Western Mediterranean and along the adjacent Atlantic margin. In Huc A. Y. (ed.), Deposition of Organic Facies, AAPG studies in geology, 30, 133-160.

Magara K. 1978. Geological models of petroleum entrapment, Elsevier, Applied Science Publishers (eds.), 328 pp.

McKenzie D. 1981. The variation of temperature with time and hydrocarbon maturation in sedimentary basins formed by extension. Earth and Planetary Science Letters, 55, 87-98.

Miller R. G. 1990. A paleoceanographic approach to the Kimmeridge clay formation. In Huc A. Y. (ed.), Deposition of Organic Facies, AAPG studies in geology, 30, 13-26.

Nichols K. M. and Silberling N. J. 1980. Eogenetic dolomitization in the Pre-Tertiary of the Great basin. In Zenger D. H., Dunham J. B. and Ethington R. L. (eds.), Concepts and models of dolomitisation, SEPM Special Publication No 28, 237-246.

Powell T. G. 1986. Petroleum geochemistry and depositional setting of lacustrine source rocks, Marine and Petroleum Geology, 3, 200-219.

Rigakis N. 1999. Contribution to stratigraphic research on wells and outcrops of the Alpine formations in Western Greece, in relation to the petroleum generation efficiency of their organic matter, Ph.D. Thesis, Athens University, 255 pp.

Rigakis N. and Karakitsios V. 1998. The source rock horizons of the Ionian basin (NW Greece), Marine and Petroleum geology, 15, 593-617.

Rigakis N., Nikolaou K., Marnelis F. and Pakos Th. 2007. The utility of oil shows in the hydrocarbon exploration of Western Greece, Bulletin of the Geological Society of Greece XXXX, 2007, Proceedings of the $11^{\text {th }}$ International Congress, 959-971.

Tissot B. P. and Welte D. H. 1984. Petroleum formation and occurrence, Springer-Verlag, 699 pp..

Tsikos H., Karakitsios V., Breugel Y., Walswarth-Bell B., Bombardiere L., Petrizzo M. R., Sinninghe Damste J. S., Schouten S., Erba E., Premoli Silva I., Farrimond P., Tyson R. V., and Jenkyns H. C. 2004. Organic-carbon deposition in the Cretaceous of the Ionian Basin, NW Greece: the Paquier Event (OAE1b) revisited, Geological Magazine, 141/4, 401-416.

Waples D. W. 1980. Time and temperature in petroleum formation: Application of Lopatin's method to petroleum exploration, AAPG Bulletin, 64, 916-926.

Zenger D. H. and Dunham J. B. 1980. Consepts and models of dolomitization - An indroduction. In Zenger D. H., Dunham J. B. and Ethington R. L. (eds.), Concepts and models of dolomitisation, SEPM Special Publication, No 28, 1-9. 